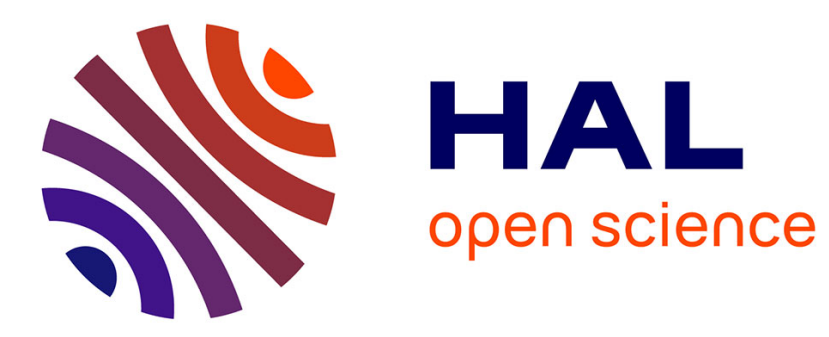

\title{
Fibers networks as a new type of core material. Processing and mechanical properties
}

Laurent Mezeix, Christophe Bouvet, Serge Crézé, Dominique Poquillon

\section{To cite this version:}

Laurent Mezeix, Christophe Bouvet, Serge Crézé, Dominique Poquillon. Fibers networks as a new type of core material. Processing and mechanical properties. Materials Research Society (MRS) 2009, Apr 2009, San Francisco, United States. pp.0. hal-01851831

\section{HAL Id: hal-01851831 https://hal.science/hal-01851831}

Submitted on 31 Jul 2018

HAL is a multi-disciplinary open access archive for the deposit and dissemination of scientific research documents, whether they are published or not. The documents may come from teaching and research institutions in France or abroad, or from public or private research centers.
L'archive ouverte pluridisciplinaire HAL, est destinée au dépôt et à la diffusion de documents scientifiques de niveau recherche, publiés ou non, émanant des établissements d'enseignement et de recherche français ou étrangers, des laboratoires publics ou privés. 


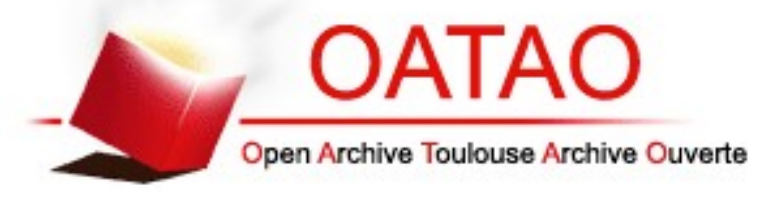

This is an author-deposited version published in: http://oatao.univ-toulouse.fr/ Eprints ID: 2987

To cite this document: MÉZEIX, Laurent. BOUVET, Christophe. CRÉZÉ, Serge. POQUILLON, Dominique. Fibers networks as a new type of core material. Processing and mechanical properties. In: Materials Research Society (MRS) 2009, 13-17 April 2009, San Francisco, USA.

Any correspondence concerning this service should be sent to the repository administrator: staff-oatao@inp-toulouse.fr 


\title{
Fibers networks as a new type of core material. Processing and mechanical properties
}

Laurent Mezeix ${ }^{1,2}$, Christophe Bouvet ${ }^{2}$, Serge Crézé $^{3}$, Dominique Poquillon ${ }^{1}$

${ }^{1}$ CIRIMAT, Université de Toulouse, INPT-ENSIACET, 118 route de Narbonne, 31077

Toulouse, France

${ }^{2}$ LGMT, IGM, Université de Toulouse, LGMT, bât 3PN, 118 route de Narbonne, 31062 , Toulouse, France

${ }^{3}$ DMSM, Université de Toulouse, ISAE campus SUPAERO, 10 avenue Edouard Belin BP 54032, 31055, Toulouse, France

\begin{abstract}
Fibers networks materials have been elaborated from different fibers: metallic fibers, glass fibers and carbon fibers. Cross-links have been achieved using epoxy spraying. The scope of this paper is to analyze the mechanical behavior of these materials and to compare it with available models. The first part of this paper deals with elaboration of fibers network materials. In the second part, compression tests are performed. The specific mechanical behavior obtained is discussed.
\end{abstract}

\section{INTRODUCTION}

Entangled materials can be made from natural materials (wool, cotton...) as well as artificial ones (steel wool, glass wool...). Bonded metal fibers network materials offer advantages [1-7] for use like heat exchanger [8] or insulation [9]. Indeed, they present a low relative density, high porosity and simplicity of production by cost-effective routes with considerable versatility concerning metal composition and network architecture.

On the other hand, sandwich panel consists of two thin skins separated by a thick core. Core material is usually in the form of honeycomb, foam or balsa. Recently, a novel type of sandwich has been developed with bonded metallic fibers as core material [10-16]. This material presents an attractive combination of properties like high specific stiffness, good damping capacity and energy absorption. Metal fibers are bonded with a polymeric adhesive [15] or fabricated in a mat-like form and consolidated by solid state sintering $[12,16]$.

Entangled cross-linked carbon fibers have been also studied for use as core material by Laurent Mezeix [17]. Indeed entangled cross-linked carbon fibers present many advantages for application as core material: open porosity, possibility to mix different fibers to optimize properties or possibility to reeve electric or control cables on core material. Only a few studies are devoted to the mechanical behavior of material made from entangled crosslinked fibers $[16,18]$.

In the present paper, fibers have been chosen in function of their nature, applications and costs. Due to their high performance, carbon fibers are intensely used in many applications: aeronautics, sport equipments or high performance vehicles. Because of their low cost, glass fibers are widely used in many applications like thermal insulation for pipe, building. Bonded metal fiber network are used as core material [10-16]. The purpose of the 
present study is to analyze the mechanical behavior and to model the initial stiffness made from three types of cross-linked fibers.

\section{EXPERIMENT}

\section{Material elaboration}

Carbon fibers (200 Tex) consist in a yarn of stranded carbon filaments. Fibers were provided by Toho Tenax. The Young modulus of the carbon fiber is $240 \mathrm{GPa}$. Fibers diameter is $7 \mu \mathrm{m}$ and the initial epoxy coating represents $1 \mathrm{wt} \%$. Assuming than the coating is uniform, then, its thickness is about $30 \mathrm{~nm}$. Stainless steel fibers were provided by UGITECH. Fibers diameter is $12 \mu \mathrm{m}$, the Young modulus is $180 \mathrm{GPa}$. Glass fibers are obtained from yarns (600 Tex) that were provided by the company PPG Fiber glass. Fibers diameter is $12 \mu \mathrm{m}$ and their Young modulus is about $73 \mathrm{GPa}$.

For aeronautical applications, many sandwich-panel skins are made using carbon/epoxy prepreg. That the reason why epoxy resin has been chosen for cross-linking fibers. Epoxy resin was provided by the company SICOMIN. The provided resin has a low viscosity ( $285 \mathrm{mPa} . \mathrm{s})$ and polymerization duration is 2 hours at $80^{\circ} \mathrm{C}$. For all the tests carried out during this work, specimens are carefully weighted using SARTORIUS balance $( \pm 10 \mu \mathrm{g})$. Resin is heated up to $35^{\circ} \mathrm{C}$ to decrease viscosity and thus allows a better vaporization.

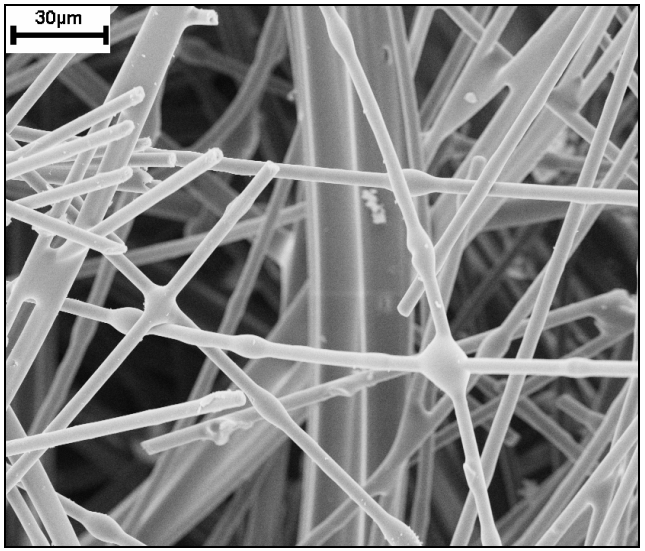

(a)

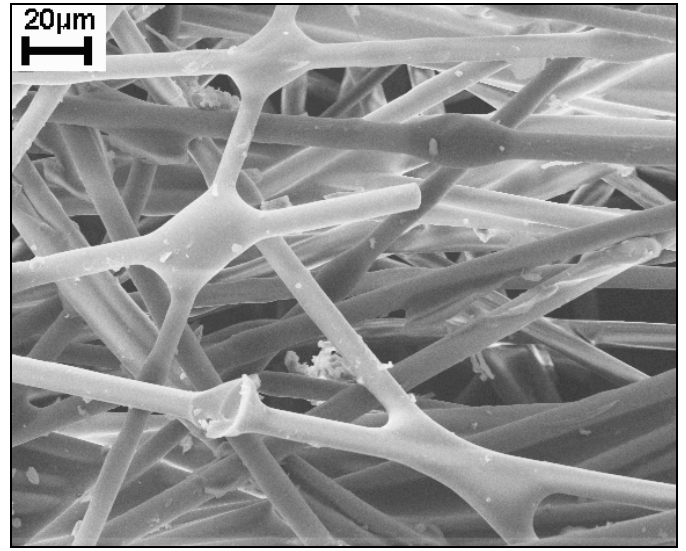

(b)

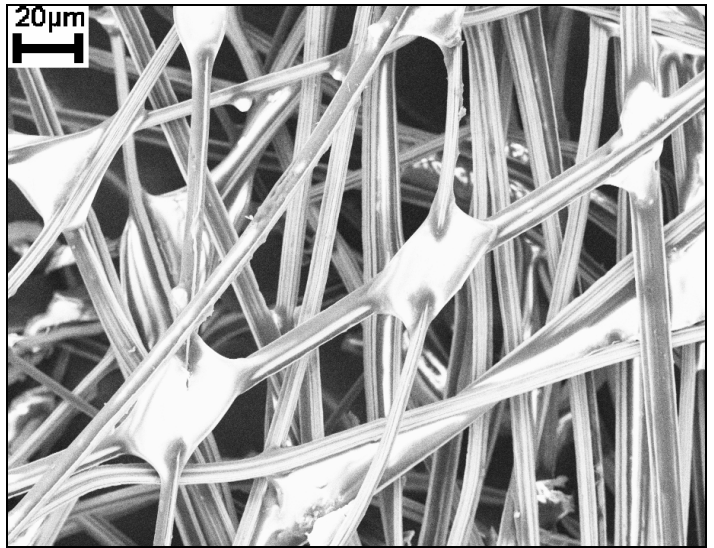

(c)

Figure 1. SEM observation on materials made with (a) cross-linked carbon fibers, (b) crosslinked glass fibers and (c) cross-linked stainless steel fibers. 
A paint spray gun (Fiac UK air compressors) is used to spray epoxy. Materials were observed using a Scanning Electron Microscope (LEO435VP) operating at $15 \mathrm{kV}$. Fibers are cut so the fibers length equals $40 \mathrm{~mm}$. For core application, one key parameter is the density. A previous study has shown that the yarns size needs to be decreased by separating filaments to obtain the lowest final density possible [19]. In the present work, separation of yarns was obtained thanks to a blower room. Then, the entangled fibers are cross-linked. In that case, epoxy is sprayed using paint spray gun during the final minutes of the entanglement. We have chosen to perform tests on fiber networks materials with fibers density of $150 \mathrm{~kg} / \mathrm{m}^{3}$. As the volume of the mould is known and the fibers mass is carefully weighted, the volumetric density is controlled. It is important to notice as the density of bulk carbon in the carbon fibers $\left(1760 \mathrm{~kg} / \mathrm{m}^{3}\right)$ is lower than the glass fibers one $\left(2530 \mathrm{~kg} / \mathrm{m}^{3}\right)$, which is lower than the stainless steel one $\left(7860 \mathrm{~kg} / \mathrm{m}^{3}\right)$, the relative volumetric density of the tests materials differs. Figure 1 shows typical SEM observations on networks made of carbon, glass and stainless steel fibers. We can notice clearly joints between filaments.

\section{Compression tests}

The quasi-static compressive response of entangled fibers is measured using a screwdriven test machine MTS with a $5 \mathrm{kN}$ load cell. The sample is introduced between the punches and the compression test is then carried out (no lateral confinement). The sample size is $30 \times 30 \times 30 \mathrm{~mm}^{3}$. The punch velocity is $\mathrm{v}_{0}=1.8 \mathrm{~mm} \cdot \mathrm{min}^{-1}$ corresponding to a nominal strain rate of $\dot{\varepsilon}=10^{-3} \mathrm{~s}^{-1}$. To analyze the experimental results, we used the usual definition for the true strain and true stress.

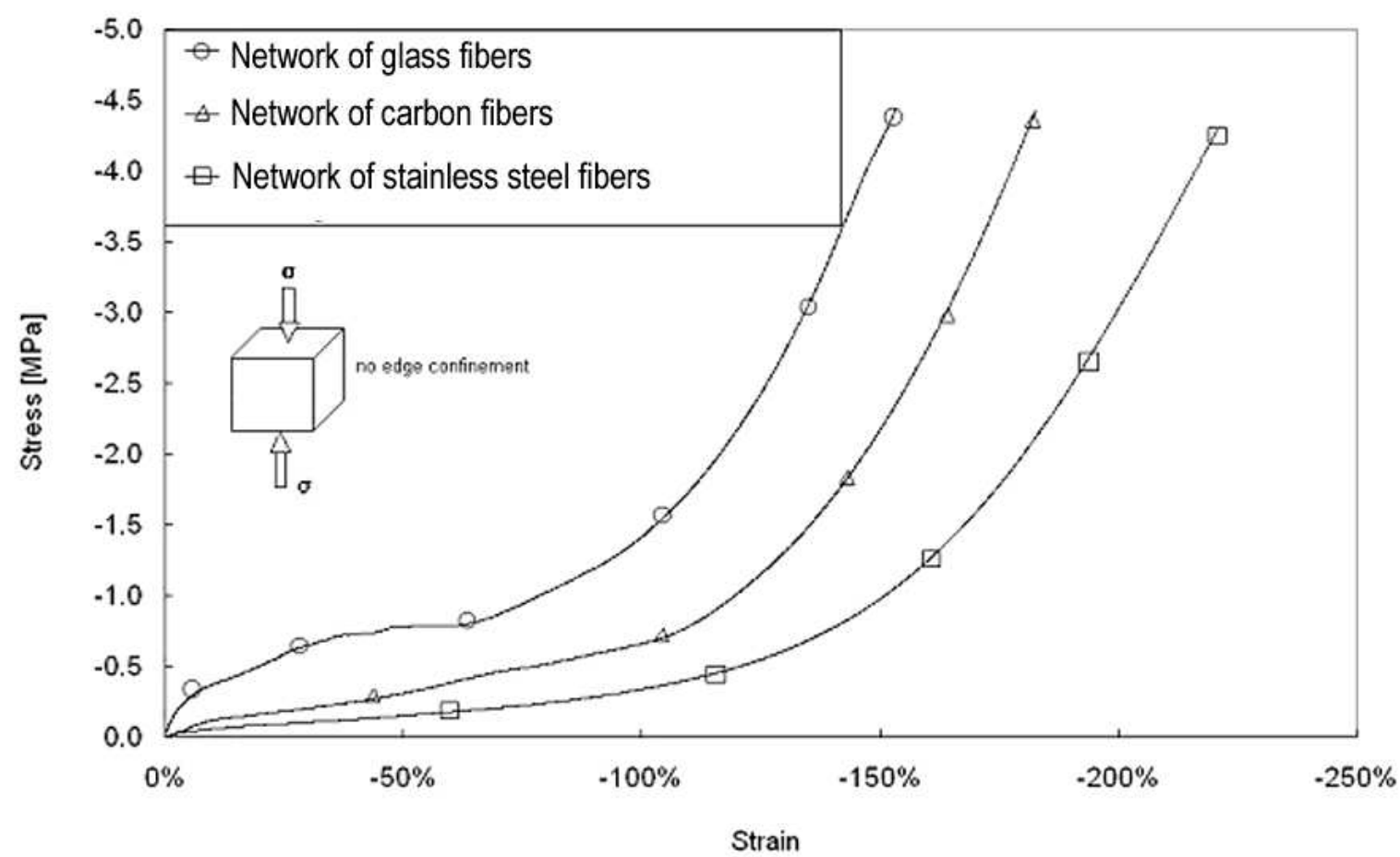

Figure 2. Comparison of compression stress/strain curves of architectures made with entangled fibers cross-linked with epoxy resin (initial density $=150 \mathrm{~kg} / \mathrm{m}^{3}$ ).

\section{RESULTS AND DISCUSSION}


Cross-linked fibers samples have been tested in compression. Density used for each type of fibers is $150 \mathrm{~kg} / \mathrm{m}^{3}$. The initial fiber density of the material is determined as explained above. The volume fraction of fiber differs between the three types of materials. $150 \mathrm{~kg} / \mathrm{m}^{3}$ correspond to a volume fraction of $1.9 \%$ for the material made of stainless steel fibers, to $5.9 \%$ for the material made of glass fibers and to $8.5 \%$ for the material made of carbon fibers. Resin is sprayed during entanglement, which is weighted again after epoxy polymerization. So the additional mass of resin can be measured and corresponds to $50 \mathrm{~kg} / \mathrm{m}^{3}$.

Figure 2 shows comparison during compression tests between materials made with cross-linked carbon fibers, stainless steel fibers and glass fibers. The better stiffness is achieved with the glass fibers. Furthermore, the plateau level [20] of stress during compression is quite high. Densification is the dominant mechanism for strain above $70 \%$. The initial stiffness of the networks glass fibers is $8.4 \mathrm{MPa}, 1.1 \mathrm{MPa}$ for carbon fibers and 0.6 MPa for stainless steel fibers. The average stress level of the plateau before densification is $0.8 \mathrm{MPa}, 0.4 \mathrm{MPa}$ and $0.25 \mathrm{MPa}$ for respectively glass, carbon and stainless steel fibers.

Table 1: Comparison of distances between cross-links.

\begin{tabular}{|c|c|c|c|}
\hline Material & $\begin{array}{c}\text { <c>, number of } \\
\text { contacts per fiber }\end{array}$ & $\begin{array}{c}\text { Average distance } \\
\text { between joints : } \\
\text { calculated value } \\
\mathbf{d}_{\mathrm{av}}=\mathbf{L} /<\mathbf{c}>\text { [mm] }\end{array}$ & $\begin{array}{c}\text { Average distance } \\
\text { between joints } \\
\text { observed by SEM } \\
\text { [mm] }\end{array}$ \\
\hline $\begin{array}{c}\text { Network of stainless } \\
\text { steel fibers }\end{array}$ & 127 & 0.31 & 0.30 \\
\hline $\begin{array}{c}\text { Network of carbon } \\
\text { fibers }\end{array}$ & 974 & 0.04 & 0.20 \\
\hline Network of glass fibers & 395 & 0.10 & 0.15 \\
\hline
\end{tabular}

In order to get a better understanding of the macroscopic behavior of the cross-linked architecture, important microscopic information is the average distance $d_{a v}$ between two cross links. An analysis of SEM pictures has been carried out and results are given in Table 2. As expected after the comparison on the compression behavior, the shortest distance $d_{a v}$ is obtained for glass fibers. This is the reason why the initial stiffness of the material is better when compared to the deflection of the beam which depends on the cubic of the distance between two cross links.

This point was not expected as the relative density of the entanglement is higher for the carbon than for the glass. Different surface properties, different reactivity with the epoxy could explain that point.

There are many discussions about the determination of the average distance between fiber contacts. Authors have proposed models to quantify the number of contacts per fiber, in layered structures [21, 22] and in three-dimensional network fibers [23, 24, 25]. The average number of contacts per fiber $\langle c\rangle$, in the case of 3D random network, is given by equation (1) as a function of $\mathrm{L}$, the fiber length, of $\mathrm{f}$, the volume fraction of fibers (f) and of $\mathrm{D}$, the fiber diameter. Then, the distance, $d_{a v}$, between joints can be obtained (see table 1) by $d_{a v}=L /\langle c\rangle$ :

$$
\langle c\rangle=2 \frac{L}{D} f
$$

If the initial density of the fibers entanglement is the same for all fibers $\left(150 \mathrm{~kg} / \mathrm{m}^{3}\right)$, the volume fraction of the three tested material is not the same. We can notice that the 
distance between joints obtained by equation (1) is closed from SEM observations for material made of glass and material made of stainless steel fibers. In the case of material made of carbon fibers, there is a large difference between the two values. Further investigations on the microscopic organization of the material elaborated in that study are still necessary. X-ray topography measurement would provide more valuable information [16].

T.W. Clyne et al. developed a simple analytical model based on the bending of inclined individual fiber segments $[18,26,27]$, the Young's modulus of the network is given as a function $\mathrm{E}_{\mathrm{f}}$, the Young's modulus of the fibers and of the geometrical parameters of the network (f, D and $d_{a v}$ ):

$$
E_{a}=\frac{9 E_{f} f}{32\left(\frac{d_{a v}}{D}\right)^{2}}
$$

The values obtained with this approach can be compared with the one given by Gibson and Ashby for open cell foams [20]. This second model is also based on beam deflections, but with different boundaries conditions (more constrained). The Young's modulus of the network is then given by:

$$
E_{a}=\frac{3 \pi E_{f}}{4\left(\frac{d_{a v}}{D}\right)^{4}}
$$

Table 2: Comparison of Young modulus obtained during compression tests with the values calculated using equations (2) and (3).

\begin{tabular}{|c|c|c|c|}
\cline { 2 - 4 } \multicolumn{1}{c|}{} & \multicolumn{3}{c|}{ E: Young modulus [MPa] } \\
\hline Material & $\begin{array}{c}\text { Calculated using } \\
\text { Eq (2) }\end{array}$ & $\begin{array}{c}\text { Calculated using } \\
\text { Eq (3) }\end{array}$ & E $_{\text {exp }}$ \\
\hline $\begin{array}{c}\text { Network of stainless steel } \\
\text { fibers }\end{array}$ & 1.7 & 1.2 & 0.6 \\
\hline Network of carbon fibers & 7.3 & 0.8 & 1.1 \\
\hline Network of glass fibers & 7.8 & 7 & 8.4 \\
\hline
\end{tabular}

Young modulus has been calculated applying equations (2) and (3) and is given in Table 2. They are compared with the experimental data (initial stiffness of the material). We can notice that the Young modulus obtained using equation (3) is closed to the experimental values for carbon and glass fibers. This point could mean that the epoxy drops at the cross links limit the deflection of fibers. In the case of stainless steel fibers, the difference between experiment and equation (3) could be explained by the plastification of fibers and the poor reticulation of the network.

Tomography data before the compression test and at the beginning of the plateau would be very useful to determine the fibers orientation, the isotropy of the initial entanglement, the average number of contacts per fibers and could help to get a better understanding of the fiber slippage and fiber orientation changes induced by compression. 
These observations are now possible and have just been achieved in another study [16]. We plan to get comparable data on our specimens.

\section{CONCLUSIONS}

Original materials have been elaborated using fibers networks bonded with epoxy resin. Three different families of fibers have been tested, glass fibers, carbon fibers and stainless steel fibers. The material obtained remains light $\left(200 \mathrm{~kg} / \mathrm{m}^{3}\right)$ as the process developed in this study optimize the quantity of epoxy used. The best stiffness is obtained for glass fibers mainly because the shortest distance between cross-links compared to the carbon case. The initial stiffness of the cross-links architecture seems to follow the model proposed by Ashby.

\section{REFERENCES}

[1] P. Ducheyne, E. Aernoudt, P. Meester, J. Mater. Sci. 13(12):2650(1978)

[2] T.W. Clyne, J.F. Mason, Metal. Trans. A 18(8):1519(1987)

[3] F. Delannay, T.W. Clyne, Proceedings of MetFoam'99, 14-16 June, Bremen, Germany (1999)

[4] Y. Yamada, C.E. Wen, Y. Chino, K. Shimojima, H. Hosokawa, M. Mabuchi, Mat. Sci. Forum 419:1013(2003)

[5] A.E. Markaki, V. Gergely, A. Cockburn, T.W. Clyne, Compos. Sci. Technol. 63(16):2345 (2003)

[6] A. Woesz, J. Stampfl, P. Fratzl, Adv. Eng. Mater. 6(3):134 (2004)

[7] M. Delince, F. Delannay, Acta Mater. 52(4):1013 (2004)

[8] L.O., Golosnoy A. Cockburn, T.W. Clyne, Adv. Eng. Mater. 10(3):210(2008)

[9] B.M. Zhang, S.Y. Zhao, X.D. He J. of Quant Spectro \& Radiat Transf 109(7):1309(2008)

[10] R. Gustavsson, AB Volvo Patent WO 98/01295, (15 ${ }^{\text {th }}$ January 1998)

[11] A.E. Markaki, T.W. Clyne, US patent 10/000117, Cambridge University (2001)

[12] A.E. Markaki, T.W. Clyne, Acta Mater. 51(5):1341 (2003)

[13] A.E. Markaki, T.W. Clyne, Acta Mater. 51(5):1351 (2003)

[14] J. Dean et al. Proceedings of ICCS8, Porto, Portugal, edited by Ferreira,: 199.

[15] D. Zhou, W.J. Stronge, Int. J. of Mech. Sci. 47(4-5):775 (2005)

[16] J.P. Masse Ph.D. Institut National Polytechnique de Grenoble, France (2009)

[17] L. Mezeix, C. Bouvet, B. Castanié, D. Poquillon (2008) Proceedings of ICCS8, Porto, Portugal, edited by Ferreira, Portugal: 798 (2008)

[18] T.W. Clyne, A.E. Markaki, J.C. Tan, Compos. Sci. and Technol. 65(15-16):2492 (2005)

[19] L. Mezeix, Material Science Master's degree, Univ. de Toulouse(2007)

[20] L.J. Gibson, M.F. Ashby, Cellular solids: structure and properties. Cambridge University Press(1997)

[21] W.J. Batchelor, J. He, W.W. Sampson, J. of Mater. Sci. 41(24):8337-8381 (2006)

[22] J. He, W.J. Batchelor, R.E. Johnston, J. of Mater. Sci. 42(2):522-528 (2007)

[23] S. Toll Polym. Eng. Sci .38:1337 (1998)

[24] C.T.J.Dodson, Tappi J 79(9):211-216(1996)

[25] A.P. Phillipse, Langmuir 12(5):1127-1133(1996)

[26] A.E. Markaki, T.W. Clyne, Biomaterials 25(19):4805 (2004)

[27] A.E. Markaki, T.W. Clyne, Acta Mater. 53(3):877 (2005) 